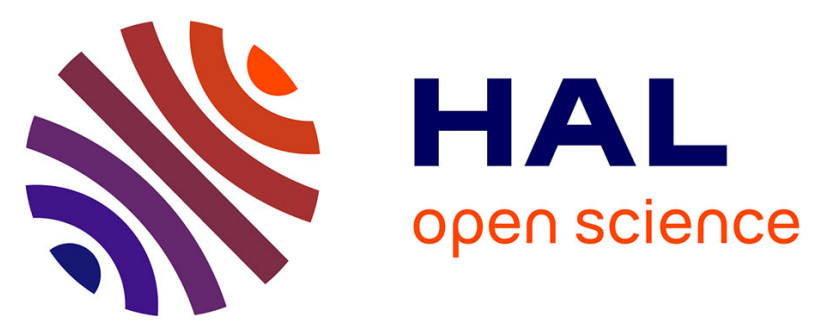

\title{
Structural and magnetic properties of nano-sized NiCuZn ferrites synthesized by co-precipitation method with ultrasound irradiation
}

Hassen Harzali, Fairouz Saida, Arij Marzouki, Adel Megriche, Fabien Baillon, Fabienne Espitalier, Arbi Mgaidi

\section{To cite this version:}

Hassen Harzali, Fairouz Saida, Arij Marzouki, Adel Megriche, Fabien Baillon, et al.. Structural and magnetic properties of nano-sized NiCuZn ferrites synthesized by co-precipitation method with ultrasound irradiation: Review. Journal of Magnetism and Magnetic Materials, 2016, 419, p. 50-56. 10.1016/j.jmmm.2016.05.084 . hal-01620294

\section{HAL Id: hal-01620294 \\ https://hal.science/hal-01620294}

Submitted on 20 Dec 2017

HAL is a multi-disciplinary open access archive for the deposit and dissemination of scientific research documents, whether they are published or not. The documents may come from teaching and research institutions in France or abroad, or from public or private research centers.
L'archive ouverte pluridisciplinaire HAL, est destinée au dépôt et à la diffusion de documents scientifiques de niveau recherche, publiés ou non, émanant des établissements d'enseignement et de recherche français ou étrangers, des laboratoires publics ou privés. 


\section{Author's Accepted Manuscript}

Structural and magnetic properties of nano-sized $\mathrm{NiCuZn}$ ferrites synthesized by co-precipitation method with ultrasound irradiation

Hassen Harzali, Fairouz Saida, Arij Marzouki, Adel Megriche, Fabien Baillon, Fabienne Espitalier, Arbi Mgaidi

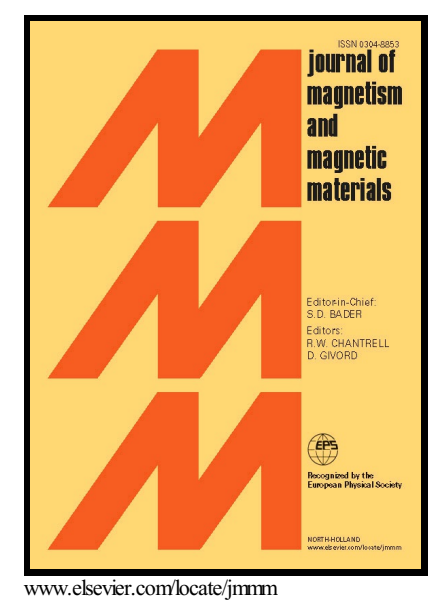

PII: S0304-8853(16)30812-5

DOI: $\quad$ http://dx.doi.org/10.1016/j.jmmm.2016.05.084

Reference: MAGMA61498

To appear in: Journal of Magnetism and Magnetic Materials

Received date: 27 February 2016

Revised date: 11 May 2016

Accepted date: 24 May 2016

Cite this article as: Hassen Harzali, Fairouz Saida, Arij Marzouki, Ade Megriche, Fabien Baillon, Fabienne Espitalier and Arbi Mgaidi, Structural anı magnetic properties of nano-sized $\mathrm{NiCuZn}$ ferrites synthesized by co precipitation method with ultrasound irradiation, Journal of Magnetism an Magnetic Materials, http://dx.doi.org/10.1016/j.jmmm.2016.05.084

This is a PDF file of an unedited manuscript that has been accepted fo publication. As a service to our customers we are providing this early version o the manuscript. The manuscript will undergo copyediting, typesetting, an review of the resulting galley proof before it is published in its final citable form Please note that during the production process errors may be discovered whic could affect the content, and all legal disclaimers that apply to the journal pertain 


\title{
ACCEPTED MANUSCRIPT
}

\section{Structural and magnetic properties of nano-sized NiCuZn ferrites synthesized by co-precipitation method with ultrasound irradiation}

\author{
Hassen Harzali ${ }^{\mathrm{a} *}$, Fairouz Saida ${ }^{\mathrm{a}}$, Arij Marzouki ${ }^{\mathrm{a}}$, Adel Megriche ${ }^{\mathrm{a}}$, Fabien Baillon ${ }^{\mathrm{b}}$, Fabienne \\ Espitalier ${ }^{\mathrm{b}}$, Arbi Mgaidi ${ }^{\mathrm{a}, \mathrm{c}}$ \\ ${ }^{a}$ Laboratory of Applied Mineral Chemistry, Faculty of Sciences, University Tunis ElManar, Campus university \\ Farhat Hached El-Manar 2092 Tunis, Tunisia \\ ${ }^{b}$ Ecole des Mines d'Albi, Centre RAPSODEE, UMR CNRS 2392, 81013 ALBI Cedex 09, France \\ ${ }^{\mathrm{c}}$ Taibah University, Faculty of Sciences \& art Al Ula Saudi Arabia SA
}

E-mail address: harzali@mines-albi.fr

\begin{abstract}
Sonochemically assisted co-precipitation has been used to prepare nano-sized $\mathrm{Ni}-\mathrm{Cu}-\mathrm{Zn}$ ferrite powders. A suspension of constituent hydroxides was ultrasonically irradiated for various times at different temperatures with high intensity ultrasound radiation using a direct immersion titanium horn. Structural and magnetic properties were investigated using $\mathrm{X}$ diffraction (XRD), FT-IR spectroscopy, transmission electron microscopy (TEM), Nitrogen adsorption at $77 \mathrm{~K}$ (BET) and Vibrating sample magnetometer (VSM). Preliminary experimental results relative to optimal parameters showed that reaction time $t=2 \mathrm{~h}$, temperature $\theta=90^{\circ} \mathrm{C}$ and dissipated Power $\mathrm{P}_{\text {diss }}=46.27$ watt. At these conditions, this work shows the formation of nanocrystalline single-phase structure with particle size 10-25 nm. Also, ours magnetic measurements proved that the sonochemistry method has a great influence on enhancing the magnetic properties of the ferrite.
\end{abstract}

Keywords: Ultrasound method; $\mathrm{Ni}_{0.4} \mathrm{Cu}_{0.2} \mathrm{Zn}_{0.4}$ ferrite nanoparticles ; Spinel structure; crystallite size, Magnetic properties.

\section{Introduction}

Commercially speaking, spinel ferrites are important materials because of their good magnetic-electrical properties [1,2]. Nanocrystalline spinel ferrites have been 


\section{ACCEPTED MANUSCRIPT}

investigated extensively due to their various applications in information storage systems, magnetic core, ferrofluids, microwave absorbers and medical diagnostics [3].

In recent years, extensive studies have been performed on the synthesis and magnetic characteristics of $\mathrm{Ni}-\mathrm{Cu}-\mathrm{Zn}$ ferrites because these materials present high electrical resistivity hard mechanical properties and also high Curie temperature and can be used for Multilayer Chip Inductor (MLCI) [4] and as transformer cores, inductors, recording heads, deflection yokes, etc [5]. According to Liu et al. [6], thin films of $\mathrm{Ni}_{0.4} \mathrm{Cu}_{0.2} \mathrm{Zn}_{0.4} \mathrm{Fe}_{2} \mathrm{O}_{4}$ can be integrated into radio frequency integrated inductors. In the present work we are interested in spinel ferrite nanoparticles with the following formula $\mathrm{NiO} .4 \mathrm{Cu} 0.2 \mathrm{Zn} 0.4 \mathrm{Fe} 2 \mathrm{O} 4$. We fixed $\mathrm{Cu}=0.2$, this value corresponds to good results of the saturation magnetization and electrical resistivity [7]. Moreover, we chose the molar ratios $\mathrm{Ni} / \mathrm{Zn}=1$ because the maximum of the saturation magnetization is obtained to this value [7].

$\mathrm{Ni}_{0.4} \mathrm{Cu}_{0.2} \mathrm{Zn}_{0.4}$ ferrites can be prepared through various wet chemical methods.

- Sol-gel method and rapid thermal annealing (RTA) was used to synthesize thin films of $\mathrm{Ni}_{0.4} \mathrm{Cu}_{0.2} \mathrm{Zn}_{0.4} \mathrm{Fe}_{2} \mathrm{O}_{4}[6]$.

- $\mathrm{Ni}_{0.4} \mathrm{Cu}_{0.2} \mathrm{Zn}_{0.4} \mathrm{Fe}_{2} \mathrm{O}_{4}$ spinel nanoparticles were obtained using reverse micelle process [8].

- Nanopowders of $\mathrm{Ni}_{0.4} \mathrm{Cu}_{0.2} \mathrm{Zn}_{0.4} \mathrm{Fe}_{2} \mathrm{O}_{4}$ were prepared by citrate precursor method followed by sintering at lower temperature [9].

- Conventional solid state reaction oxide method and calcination at higher temperature was also used to prepare nanopowders of this ferrite [10].

- Single-phase nano-crystalline $\mathrm{Ni}_{0.4} \mathrm{Cu}_{0.2} \mathrm{Zn}_{0.4} \mathrm{Fe}_{2} \mathrm{O}_{4}$ ferrites were successfully prepared through cheap and environmentally friend gelatin precursor method [11].

Nanocrystalline spinel ferrite $\mathrm{MFe}_{2} \mathrm{O}_{4}(\mathrm{M}=\mathrm{Ni}, \mathrm{Zn})$ powders were obtained via novel hydrothermal method using aloe vera plant extracted solution [12]. Authors conclude that hydrothermal route is very versatile for the synthesis of nanophase materials because reactions and phase formation occurred in closed systems at low temperatures (less than $200^{\circ} \mathrm{C}$ ). Microwave assisted-hydrothermal was also tested as novel processing to synthesize ferromagnetic $\mathrm{Ni}_{0.9} \mathrm{Fe}_{2.1} \mathrm{O}_{4}$ and paramagnetic $\mathrm{Zn}_{1.1} \mathrm{Fe}_{1.09} \mathrm{O}_{4}$ ferrites [13]. 


\section{ACCEPTED MANUSCRIPT}

In all methods used, the shape, the size distribution and the crystalinity of the final product can be precisely controlled through adjusting the reaction parameters such as temperature, time, solvent, and precursor type [14-17]. The physical properties of the spinel type nanoparticles such as magnetic, microwave and doping effects are determined by the particle size and shape as well as the type and the degree of defectiveness of the crystal lattice in which a total of 24 metal cations are partitioned between eight tetrahedral $\left(8 \mathrm{Fe}^{2+}\right)$ and 16 octahedral $\left(16 \mathrm{Fe}^{3+}\right)$ interstices.

To our knowledge no literature was found on sonochemistry synthesized NiCuZn ferrites. To avoid agglomeration of nanoparticles, sonochemical route was adopted to investigate the mechanism of $\mathrm{Zn}$ ferrite particles synthesized under ultrasound conditions [18].

$\mathrm{Ni}-\mathrm{Cu}$ ferrite nanopowders were obtained by coprecipitation method with ultrasound irradiation [19]. This work concludes that only single phase of $\mathrm{Cu}_{1-\mathrm{x}} \mathrm{Ni}_{\mathrm{x}} \mathrm{Fe}_{2} \mathrm{O}_{4}$ was obtained under these conditions otherwise the $\mathrm{Cu}^{2+}$ complexation will occurs.

In our previous work [20], we have elucidate the positive influence of ultrasound on crystallization processes through the reduction of the induction time, metastable zone width, the modification of the crystals size distribution and the increase in the number of crystals at equivalent supersaturation. So we concluded that the sonochemical process appears to be an attractive method for preparing several fine substances such as ferrites. Therefore, in the present work, it is aimed at carrying out a systematic study of nano-sized $\mathrm{Ni}_{0.4} \mathrm{Cu}_{0.2} \mathrm{Zn}_{0.4} \mathrm{Fe}_{2} \mathrm{O}_{4}$ ferrites synthesized by co-precipitation method with ultrasound irradiation. One of the motivations of this study is to show if a minimum energy and minimum synthesis duration exists with method assisted by ultrasound. For these reasons, the temperature effect and the time effect have been studied in this work.

\section{Experimental}

\subsection{Preparation of powders}

The initial chemicals were analytical grade nickel sulfate $\left[\mathrm{NiSO}_{4} \cdot 6 \mathrm{H}_{2} \mathrm{O}\right]$, copper sulfate $\left[\mathrm{CuSO}_{4} .5 \mathrm{H}_{2} \mathrm{O}\right]$, iron nitrate $\left[\mathrm{Fe}\left(\mathrm{NO}_{3}\right)_{3} .9 \mathrm{H}_{2} \mathrm{O}\right]$ and zinc sulfate $\left[\mathrm{ZnSO}_{4} .7 \mathrm{H}_{2} \mathrm{O}\right]$. Stoichiometric amounts of each chemical necessary for the preparation of $\mathrm{Ni}_{0.4} \mathrm{Cu}_{0.2} \mathrm{Zn}_{0.4} \mathrm{Fe}_{2} \mathrm{O}_{4}$ were carefully dissolved in $10 \mathrm{~g}$ deionized water. After dissolution (the conductivity of solution was monitored), the obtained solutions were mixed. The $\mathrm{pH}$ of the final solution was adjusted to 12 using $\mathrm{NaOH}$ solution. 
The experimental apparatus used for the synthesis is represented first by a thermostated vessel $(100 \mathrm{~mL})$ which was stirred with a magnetic stir bar at a constant rotation speed of about 200 rpm. Second, by ultrasound that was applied at the top of the liquid by a stainless tip transducer with a diameter of $1.1 \mathrm{~cm}$, immersed at a $1 \mathrm{~cm}$ depth in the vessel. Three ultrasonic power levels, measured in water by the calorimetric method at $25{ }^{\circ} \mathrm{C}$, were used corresponding to dissipated powers of 28.03 (Amplitude 30\%), 38.23 (Amplitude 40\%) and 46.27 Watt (Amplitude 50\%) [21]. The solution temperature is measured with an instrumental resolution of $0.01{ }^{\circ} \mathrm{C}$. Three temperature values were used in this work $\left(70,90\right.$ and $\left.100{ }^{\circ} \mathrm{C}\right)$.

The resulting brown powders were collected by filtration and washed (hydrochloric acid and distilled water were used) to remove any possible impurities. The product was finally dried at $100{ }^{\circ} \mathrm{C}$ in an oven during $24 \mathrm{~h}$.

\subsection{Techniques}

- $\quad$ X-ray powder diffraction patterns are recorded using a panalyticalX'pert-pro X-ray diffractometer operating with Co Ka radiation.

- $\quad$ Fourier transform infrared spectra (FT-IR) for the powders are recorded on a PerkinElmer 883 spectrophotometer from 4000 to $200 \mathrm{~cm}^{-1}$ by the $\mathrm{KBr}$ pellet method.

- Morphological observation was performed using a transmission electron microscopy (TEM) system. Nanoparticles size and morphology were studied with a JEOL Model JEM $100 \mathrm{CX}$ electron microscope having an acceleration voltage of $100 \mathrm{kV}$. High-resolution transmission electron microscopy observations were performed using a JEOL2010 microscope of $200 \mathrm{kV}$. Samples for TEM were prepared by placing a drop of NP solution on a carbon coated copper grid. The size distributions are determined with Image $\mathbf{J}$ software $(1.37 \mathrm{v})$ by measuring the diameter of around 100 nano-particules.

- $\quad \mathrm{N} 2$ adsorption isotherms of the dried products were measured at $77 \mathrm{~K}$ on a Micromeritics ASAP 2020 instrument. The samples were kept in vacuum at $323 \mathrm{~K}$ for $2 \mathrm{~h}$ to remove adsorbed gases before the measurement. The specific surface areas and the pore-size were determined using the Brunauer-Emmett-Teller (BET) and the Barrett-Joyner-Halenda (BJH) methods, respectively. 


\section{ACCEPTED MANUSCRIPT}

- Magnetic properties such as saturation magnetization are investigated using vibrating sample magnetometer (VSM, LakeShore 7400) at room temperature.

\section{Results and discussion}

\subsection{Dissipated power}

The Cavitation intensity, can be thought of as the product of bubble collapse (or implosion) pressure times the number of bubbles collapsing, is linked to the local ultrasonic power which affects the cavitation regimes (dynamics of oscillating bubbles). The calorimetric method is used because all the energy entering into the calorimeter is expected to be transformed into heat.

In the present work, a temperature probe, with resolution of $0.01^{\circ} \mathrm{C}$, has been used in order to measure the dissipated power in our reactor.

The dissipated power, $\mathrm{P}_{\text {diss }}$ (ultrasound power), was estimated by calorimetry and calculated using the following equation:

$$
\mathrm{P}_{\text {diss }}=\mathrm{mC}_{\mathrm{p}}(\mathrm{T} / t)_{\mathrm{t}=0}
$$

Where $\mathrm{m}, \mathrm{C}_{\mathrm{P}}$ and $\mathrm{T}$ denote the solution mass, the specific heat of water and the initial slope of the curve of temperature versus time respectively. A known mass of water was added in the sono-reactor. Measurements of dissipated acoustic power in the sono-reactor were recorded for different amplitude (30, 40 and 50\%). The calorimetric measurements have been done with water in the cooling jacket and with stirring during the measurements [21]. The obtained dissipted power $\mathrm{P}_{\text {diss }}$ are summarized in table 1:

\section{Table 1}

\subsection{X-ray diffraction}

- The time effect

The X-ray diffraction patterns recorded for the synthesized ferrite nanocrystals with variation of time at the same temperature and dissipated power $\left(90^{\circ} \mathrm{C}, 46.27 \mathrm{Watt}\right)$ are shown in Fig. 1. The existence of the (220), (311), (400), (422), (511) and (440) major crystal plane in the XRD patterns confirms the formation of spinel cubic structure with the Fd3m space group. Weak diffraction peaks at 38 and $46^{\circ}$ were observed for samples synthesized at 0.75 and 1 hour (Fig. 1). These peaks are attributed to hematite $\left(\alpha-\mathrm{Fe}_{2} \mathrm{O}_{3}\right)$ and to $\mathrm{CuO}[22,23]$. These peaks completely disappear when the synthesis duration begins high to 1 hour. From 1.5 hours of synthesis duration, the samples were considered to be single-phase spinel structure as 
no extra peaks and no unreacted constituents were observed. In Table 2, we reported the optimal reaction time and temperature observed in the other chemical routes for $\mathrm{NiCuZn}$ ferrites synthesis.

\section{Fig. 1}

\section{Table 2}

The crystallite size for all samples estimated from XRD peak broadening using Scherrer's formula:

$$
\mathrm{d}=0.9 \lambda / \beta \cos \theta
$$

Where $d$ is the crystallite size, $\lambda$ is the wavelength of $\mathrm{X}$-ray radiation $(\mathrm{Co} K \alpha), \theta$ is the Bragg angle and $\beta$ is the full width at half maximum (FWHM) of all diffraction peaks.

The obtained lattice parameters, crystallite size and cell volume for the nanocrystals are listed in Table 3 [24]. The average crystallite size is increasing with a synthesis time duration.

\section{Table 3}

\section{- The temperature effect}

Fig. 2 shows the XRD patterns collected on particles synthesized at 70,90 and $100{ }^{\circ} \mathrm{C}(\mathrm{t}=2$ hours and dissipated power $=46.27$ Watt). For all samples, the existence of the major crystal plane in the XRD patterns confirms the formation of spinel cubic structure with the $\mathrm{Fd} 3 \mathrm{~m}$ space group. The samples were considered to be single-phase spinel structure. We can notice that ultrasound has probably the major effect in the precipitation process compared to the temperature effect.

\section{Fig. 2}

Also, samples could be considered as a single-phase spinel structure. However as it can be seen there is a right shift diffractograms with increasing temperature. Several studies confirmed the increasing of crystallite size with temperature. Table 4 summarized the values of crystalliste size, the lattice parameters and the corresponding cell volume at different temperatures.

\section{Table 4}


As it can be seen from this Table, the crystallite size increases with increasing temperature and the lattice parameters decrease slightly with temperature increasing. This result confirms the right shift of diffractograms XRD reported in Fig.2. In this work, we have chosen the optimal temperature $=90^{\circ} \mathrm{C}$.

\section{- The dissipated power effect}

The X-ray diffraction patterns recorded for the synthesized ferrite nanocrystals with variation of dissipated power at the same temperature and duration time $\left(90^{\circ} \mathrm{C}, 2\right.$ hours $)$ are shown in Fig. 3. The XRD results of figure 3 suggest that $\mathrm{Ni}_{0.4} \mathrm{Cu}_{0.2} \mathrm{Zn}_{0.4} \mathrm{Fe}_{2} \mathrm{O}_{4}$ samples crystallized in single-phase spinel structure with the group space $(\mathrm{Fd} 3 \mathrm{~m})$.

\section{Fig. 3}

From this figure, we note that the peak (220) appears correctly from $\mathrm{P}_{\text {diss }}=38.23$ and we have observed also that crystallite size increases with increasing dissipated power (see Table 5).

\section{Table 5}

\subsection{FT-IR measurements}

The obtained powders $\mathrm{Ni}_{0.4} \mathrm{Cu}_{0.2} \mathrm{Zn}_{0.4} \mathrm{Fe}_{2} \mathrm{O}_{4}$ were also investigated by Fourier transform infrared spectroscopy. The FTIR spectra in the frequency range $800-400 \mathrm{~cm}^{-1}$ are shown in Fig. 4.

\section{Fig. 4}

As it can be seen from this figure that FTIR spectra of the investigated samples exhibit two absorption bands around 400 and $600 \mathrm{~cm}^{-1}$. These bands are characteristic of spinel ferrites and attributed to the vibrations of the metal ion-oxygen complexes in the tetrahedral and octahedral sites [10]. The high frequency band appearing near $600 \mathrm{~cm}^{-1}$ was attributed to stretching mode of tetrahedral group (noted $v_{1}$ ) and that lower band near the $420 \mathrm{~cm}^{-1}$ was assigned to octahedral cluster. We observed also change in the position band $v_{1}$ which is related to increasing of particle size [7]. 


\section{ACCEPTED MANUSCRIPT}

\subsection{Surface area and porosity measurements}

The adsorption-desorption isotherm of nitrogen at $77 \mathrm{~K}$ for $\mathrm{Ni}_{0.4} \mathrm{Cu}_{0.2} \mathrm{Zn}_{0.4} \mathrm{Fe}_{2} \mathrm{O}_{4}$ ferrites (Figure 5 and 6) are of Type IV isotherms with Type H2 hysteresis loops, according to the classification of the IUPAC [25], the initial part of the Type IV isotherm is attributed to monolayer-multilayer adsorption. Hysteresis appearing in the multilayer range of physisorption isotherms is usually associated with capillary condensation in mesopore structures. The $\mathrm{H} 2$ hysterisis loop is the characteristic of mesopore structures.

\section{Fig. 5}

Fig. 6

Textural parameters derived from nitrogen adsorption-desorption isotherm data are summarized in Table 6. As can be noted, the effect of temperature and dissipated power on $\mathrm{Ni}_{0.4} \mathrm{Cu}_{0.2} \mathrm{Zn}_{0.4} \mathrm{Fe}_{2} \mathrm{O}_{4}$ ferrites was accompanied by a marked increase in surface area and pore volume.

\section{Table 6}

\subsection{Morphological study}

Fig.7 shows the TEM image of $\mathrm{Ni}_{0.4} \mathrm{Cu}_{0.2} \mathrm{Zn}_{0.4} \mathrm{Fe}_{2} \mathrm{O}_{4}$ synthesized at $\mathrm{T}=90^{\circ} \mathrm{C}, \mathrm{t}=2$ hours and for $\mathrm{P}_{\mathrm{diss}}=46.26$ Watt deposited on carbon coated copper grid at $50 \mathrm{~nm}$ resolution. It can be seen, that powders have uniform shapes and well dispersed. The average particle sizes were measured in TEM micrographs and were found to be in the range of 10-25 $\mathrm{nm}$. These values were, similar to the ones, calculated using the XRD measurements.

\section{Figure 7}

\subsection{Magnetic properties}

The magnetic properties are the most important properties of ferrites depending on the synthesis method, processing conditions, microstructure and chemical composition. The change in the magnetic properties can be attributed to the influence of the cationic stochiometry and their occupancy in the specific sites. In the spinel ferrites, it is well known that $\mathrm{Zn}^{2+}$ ions prefer the occupation of tetrahedral (A) sites [26,27], $\mathrm{Ni}^{2+}$ and $\mathrm{Cu}^{2+}$ ions prefer the occupation of octahedral (B) sites while $\mathrm{Fe}^{3+}$ ions partially occupy the A and $\mathrm{B}$ sites. $\mathrm{Fe}^{3+}$ $\left(\mathrm{d}^{5}\right), \mathrm{Ni}^{2+}\left(\mathrm{d}^{8}\right), \mathrm{Cu}^{2+}\left(\mathrm{d}^{9}\right)$ and $\mathrm{Zn}^{2+}\left(\mathrm{d}^{10}\right)$ cations of the ferrite have 5, 2, 1, and 0 unpaired 


\section{ACCEPTED MANUSCRIPT}

electrons respectively and some magnetic moment in $\mu_{\mathrm{B}}$ considering complete unquenched orbital moment.

For $\mathrm{Ni}_{0.4} \mathrm{Cu}_{0.2} \mathrm{Zn}_{0.4} \mathrm{Fe}_{2} \mathrm{O}_{4}$ nanopowders synthesized at different conditions, we have investigated their magnetic properties using a Magnetometer (VSM) at room temperature. Fig. $8(a, b, c)$ shows the M-H curves of the ferrites at different conditions.

Fig. 8

From this figure, we can conclude that the saturation magnetization (Ms) values increases with the duration time (Fig. 8 a) and with dissipated power (fig. 8 c). The higher value of Ms (55.72 $\mathrm{Am}^{2} \cdot \mathrm{kg}^{-1}$ ) is obtained for $\mathrm{Ni}_{0.4} \mathrm{Cu}_{0.2} \mathrm{Zn}_{0.4} \mathrm{Fe}_{2} \mathrm{O}_{4}$ synthesized at $\mathrm{T}=90^{\circ} \mathrm{C}, \mathrm{t}=2$ hours and for $\mathrm{P}_{\mathrm{diss}}=46.27$ Watt. The coercive field $(\mathrm{Hc})$ is of the order of $3.910^{-3} \mathrm{~T}$ for all the ferrites which is indicating that the $\mathrm{Ni}_{0.4} \mathrm{Cu}_{0.2} \mathrm{Zn}_{0.4}$ ferrite could be used in high-density data storage devices [28].

Hysteresis loops in Fig. 8 are typical for soft magnetic materials and the "S" shape of the curves together with the negligible coercivity $(\mathrm{Hc}=39 \mathrm{Oe})$ indicate the presence of small magnetic particles exhibiting superparamagnetic behaviors [29]. Literature data imply that when the diameter of particles is less than $30 \mathrm{~nm}$, the particles show the character of superparamagnetism [29].

The annealing temperature dependence of saturation magnetization $\left(\mathrm{M}_{\mathrm{s}}\right)$ and the coercivity $\mathrm{Hc}$ for the $\mathrm{Ni}_{0.4} \mathrm{Cu}_{0.2} \mathrm{Zn}_{0.4} \mathrm{Fe}_{2} \mathrm{O}_{4}$ was observed in earlier work [28]. The authors concluded changes in the magnetic properties of the samples can be attributed to the modification of the crystallite sizes. The increase in saturation magnetization was most likely attributed to the increasing of particle size and can be explained on the basis of changes in exchange interactions between tetrahedral and octahedral sub-lattices [29].

As can be noted, with the use of ultrasound in the synthesis (without calcination), we can obtain a good Ms compared to other methods (table 7).

\section{Table 7}

\section{Conclusions}

Sonochemically assisted co-precipitation method was used to prepare the $\mathrm{NiCuZn}$ ferrites. The structure and magnetic properties have been investigated and the following results have been obtained: 


\section{ACCEPTED MANUSCRIPT}

- A single-phase $\mathrm{Ni}-\mathrm{Cu}-\mathrm{Zn}$ ferrite with cubic spinel structure without any secondary phase was formed and no extra lines corresponding to any other phases could be detected.

- The crystallite size of synthesized nanocrystals was calculated using Scherrer's formula and TEM images. The range of crystallite size lied between 10 and $25 \mathrm{~nm}$.

- The saturation of magnetization (Ms) increases with increasing the crystallite size.

-The optimal value of Ms was obtained for the sample synthesized at these initial conditions (reaction time $=2$ hours, temperature $=90^{\circ} \mathrm{C}$ and dissipated power Pdiss $=46 \mathrm{Watt}$ ).

\section{References}

[1] T. Abraham, J. Am. Ceramic. Soc. Bull. 73 (1994) 62.

[2] S.W. Lee, S.H. Yonn, S.Y. An, W.C. Kim, C.S. Kim, J. Magn. 4 (1999) 115.

[3] A. Baykal, N. Kasapoğlu, Y. Köseoğlu, M.S. Toprak, H. Bayrakdar, J. Alloys Compd. 464 (2008) 514.

[4] Z. Yue, L. Li, J. Zhou, H. Zhang, Z. Ma, Z. Gui, J. Mater. Lett. 44 (2000) 279.

[5] S. Ramesh, B. Chandra Sekhar, P.S.V. Subba Rao, B. Parvatheeswara Rao, Ceram Int. 40 (2014) 8729.

[6] F. Liu, T.Ren, C.Yang, L.Liu, A.Z.Wang, J.Yu, Materials letters 60 (2006) 1403.

[7] J. H. Nam, S. J. Park, W. K. Kim, IEEE Trans. Magn. 39 (2003) 3139.

[8] A. Ghasmi, J. Magn. Magn.Mater. 360 (2014) 41.

[9] M. C. Dimri, A. Verma, S. C. Kashyap, D.C. Dube, O. P. Thakur, C.Prakash, Mater. Sci. Eng. B 133 (2006) 42.

[10] M.M. Eltabey*, K.M. El-Shokrofy, S.A. Gharbia, J. Alloys Compd. 509 (2011) 2473.

[11] M.A. Gabal, Y.M. Al Angari, A.Y. Obaid, A. Qusti, Advanced Powder Technology, 25 (2014) 457.

[12] S. Phumying, S. Labuayai, E. Swatsitang, V. Amornkitbamrung, S. Maensiri, Mat. Res. Bull. 48 (2013), 2060.

[13] R.S. Melo, F.C.Silva, K.R.M. Moura, A.S. de Menezes, F.S.M. Sinfrônio, J. Magn. Magn.Mater. 381(2015)109.

[14] N.Y. Mostafa, E.A. Kishar, S.A. Abo-El-Enein, J. Alloys Compd. 473 (2009) 538. 


\section{ACCEPTED MANUSCRIPT}

[15] N.Y. Mostafa, A.A. Shaltout, H. Omar, S.A. Abo-El-Enein, J. Alloys Compd. 467 (2009) 332.

[16] W.L. Suchanek, R.E. Riman, Adv. Sci. Tech. 45 (2006) 184.

[17] S. Kumar, R. Kumar, S.K. Sharma, V.R. Reddy, A. Banerjee, Alimuddin, J. Solid St. Comm. 142 (2007) 706.

[18] HA. Choudhury, A. Choudhary, M. Sivakumar, VS.Moholkar, Ultrason Sonochem. 1 (2013) 294.

[19] SG.Doh, EB. Kim, BH. Lee, JH. Oh, J. Magn. Magn. Mater. 3 (2003) 2238.

[20] H. Harzali, F. Baillon, O. louisnard, F. Espitalier, A. Mgaidi, Ultrason Sonochem. 18 (2011) 1097.

[21] H. Harzali, F. Baillon, O. louisnard, F. Espitalier, A. Mgaidi, Chem. Eng. J. 195 (2012) 332.

[22] D.P. Volanti, D. Keyson, L.S. Cavalcante, A.Z. Simoes, M.R. Joya, E. Longo, J.A. Varela, P.S. Pizani, A.G. Souza, J. Alloys Compd.459 (2008) 537.

[23] F. Liu, C.Yang, T. Ren, A.Z. Wang, J. Yu, L.Liu, J. Magn. Magn. Mater. 309 (2007) 75.

[24] B.D. Cullity, $2^{\text {nd }}$ ed., Addison Wesley, Reading, MA, (1978) 99.

[25] B. Abida , L. Chirchi, S. Baranton, T.W. Napporn, H. Kochkar, J.M. Léger, A.Ghorbel, Appl. Catal., B. 106 (2011) 609.

[26] M.A. Ahmed, E. Ateia, L.M. Salah, A.A. El-Gamal, J. Mater. Chem. Phys. 92 (2005) 310.

[27] A.M. El-Sayed, J. Mater. Chem. Phys. 82 (2003) 583.

[28] M. C. Dimri, A. Verma, S. C. Kashyap, D.C. Dube, O. P. Thakur, C.Prakash, Materials Science and Engineering. 133 (2006) 42.

[29] Manova E, Tsoncheva T, Estournes C, Paneva D, Tenchev K, Mitov I, Petrov L, Appl. Catal., A. 300 (2006) 170.

[29] Nawale AB, Kanhe NS, Patil KR, Bhoraskar SV, Mathe VL, Das AK, J. Alloys Compd., 509 (2011) 4404. 


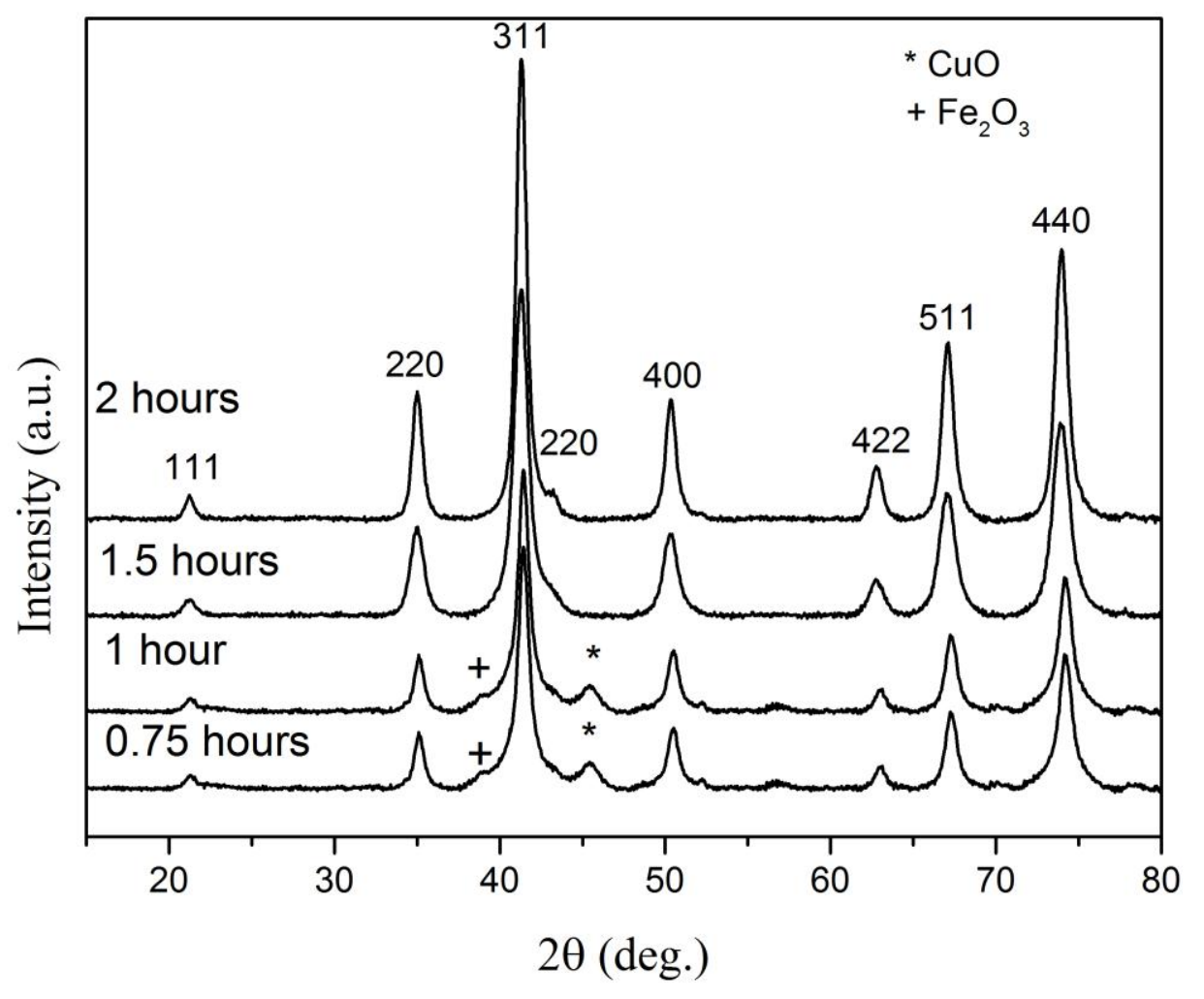

Figure 1: Powder XRD pattern for the samples synthesized at different times. 


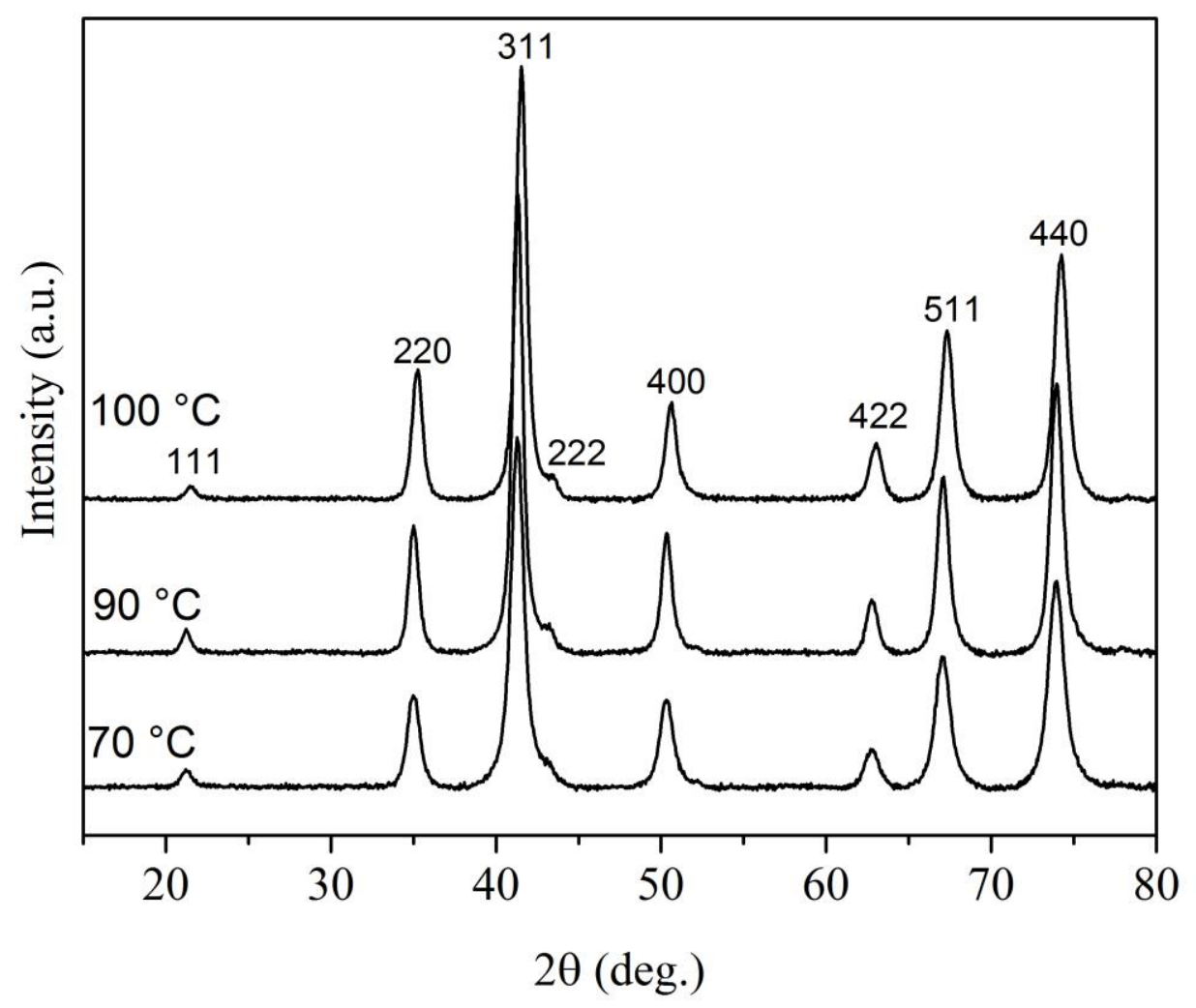

Figure 2: X-ray diffraction patterns for $\mathrm{Ni}_{0.4} \mathrm{Cu}_{0.2} \mathrm{Zn}_{0.4} \mathrm{Fe}_{2} \mathrm{O}_{4}$ samples synthesized at 70,90 and $100{ }^{\circ} \mathrm{C}$ for 2 hours $\left(\mathrm{P}_{\text {diss }}=46.27 \mathrm{Watt}\right)$. 


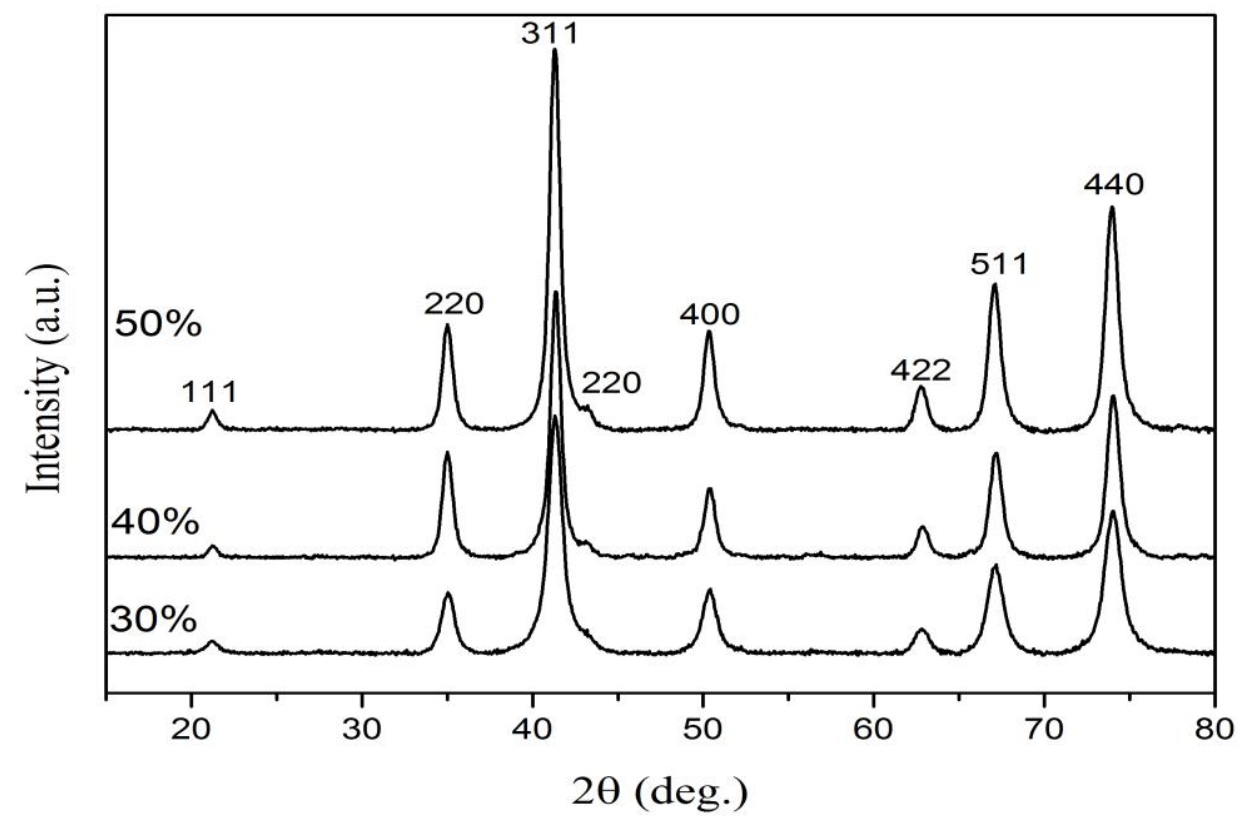

Figure 3: X-ray diffraction patterns for the samples $\mathrm{Ni}_{0.4} \mathrm{Cu}_{0.2} \mathrm{Zn}_{0.4} \mathrm{Fe}_{2} \mathrm{O}_{4}$ at different delivered power (table 1). 

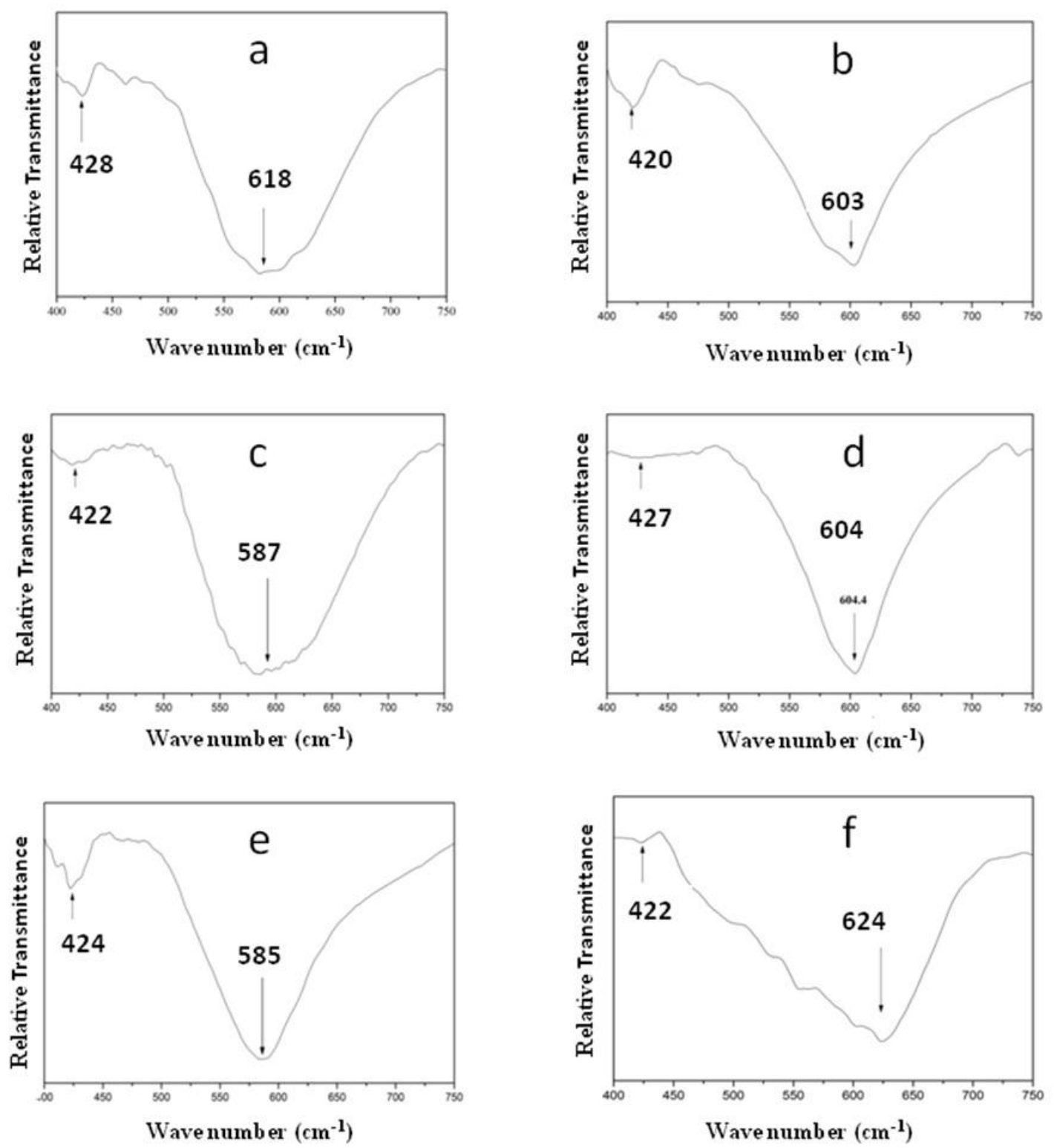

Figure 4: FT-IR spectra of $\mathrm{Ni}_{0.4} \mathrm{Cu}_{0.2} \mathrm{Zn}_{0.4} \mathrm{Fe}_{2} \mathrm{O}_{4}$ ferrites.
(a) time $=1.5 \mathrm{~h} ; \theta=90^{\circ} \mathrm{C} ; \mathrm{P}_{\text {diss }}=46.27 \mathrm{Watt}$
(b) time $=2.0 \mathrm{~h} ; \theta=90^{\circ} \mathrm{C} ; \mathrm{P}_{\text {diss }}=46.27 \mathrm{Watt}$
(c) time $=2.0 \mathrm{~h} ; \theta=70^{\circ} \mathrm{C} ; \mathrm{P}_{\text {diss }}=46.27 \mathrm{Watt}$
(d) time $=2.0 \mathrm{~h} ; \theta=100^{\circ} \mathrm{C} ; \mathrm{P}_{\text {diss }}=46.27 \mathrm{Watt}$
(e) time $=2.0 \mathrm{~h} ; \theta=90^{\circ} \mathrm{C} ; \mathrm{P}_{\text {diss }}=38.23 \mathrm{Watt}$
(f) time $=2.0 \mathrm{~h} ; \theta=90^{\circ} \mathrm{C} ; \mathrm{P}_{\text {diss }}=28.03 \mathrm{Watt}$ 


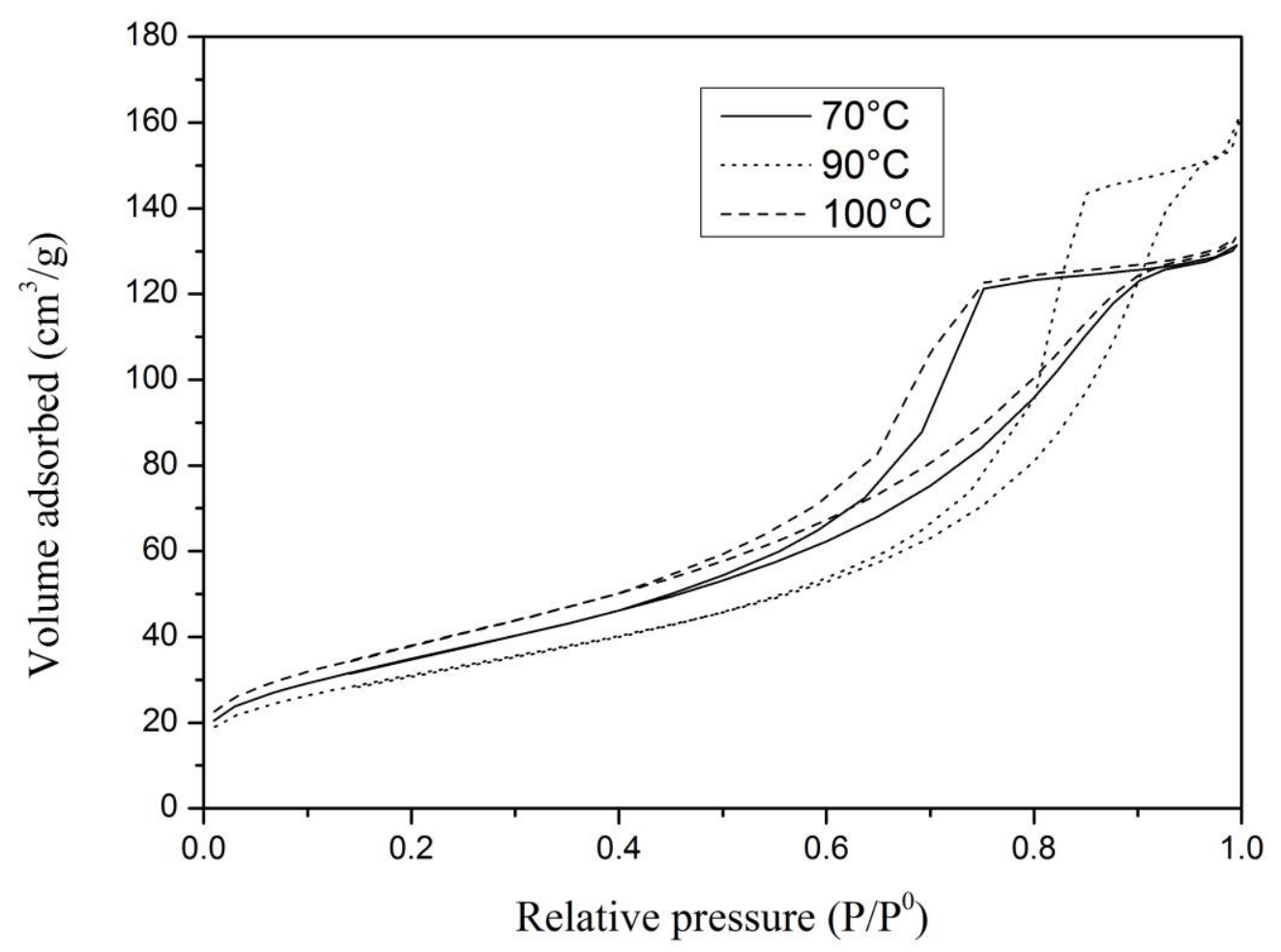

Figure 5: BET surface area (effect of synthesis temperature). 


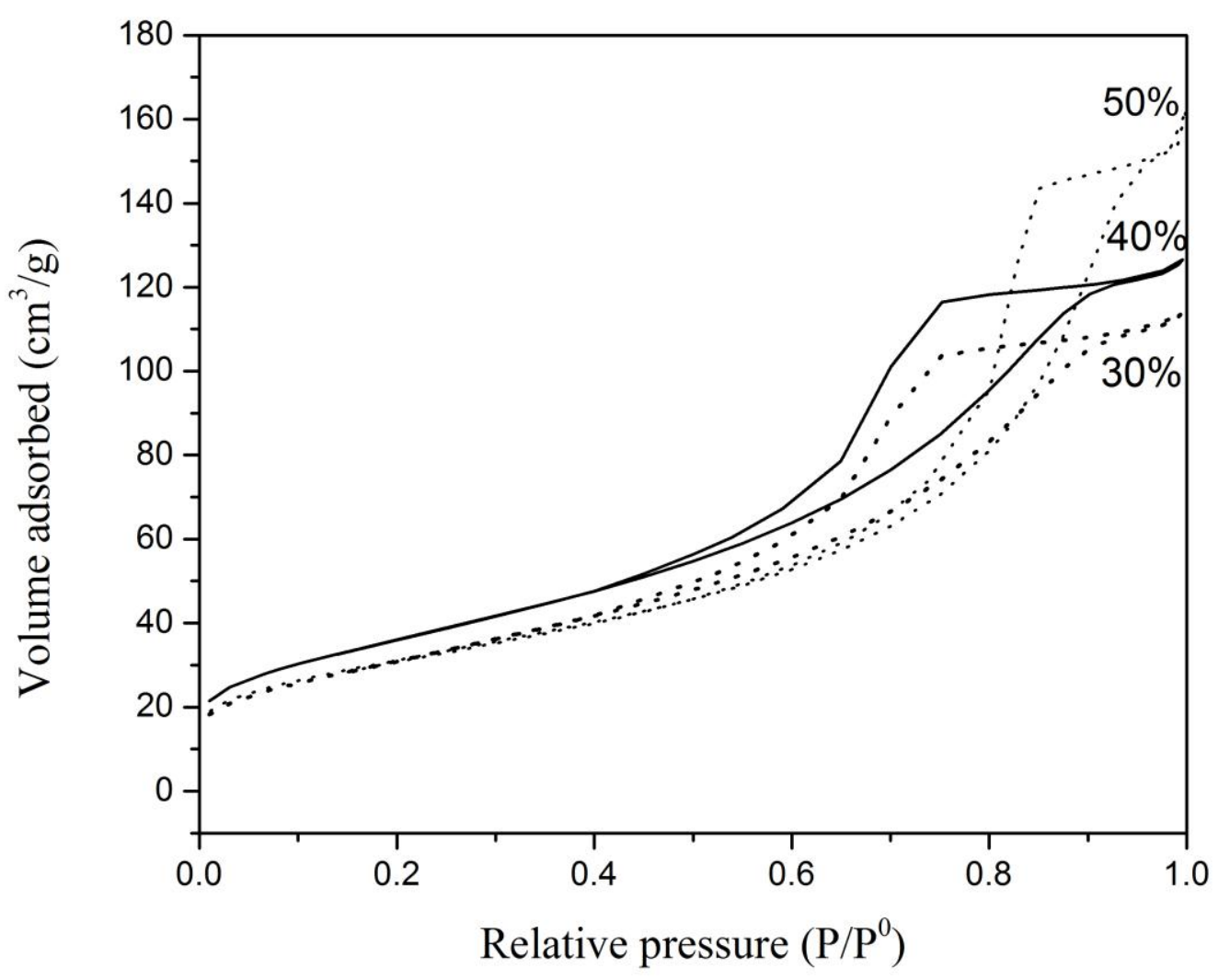

Figure 6: BET surface area (dissipated power effect; table 1). 


\section{ACCEPTED MANUSCRIPT}

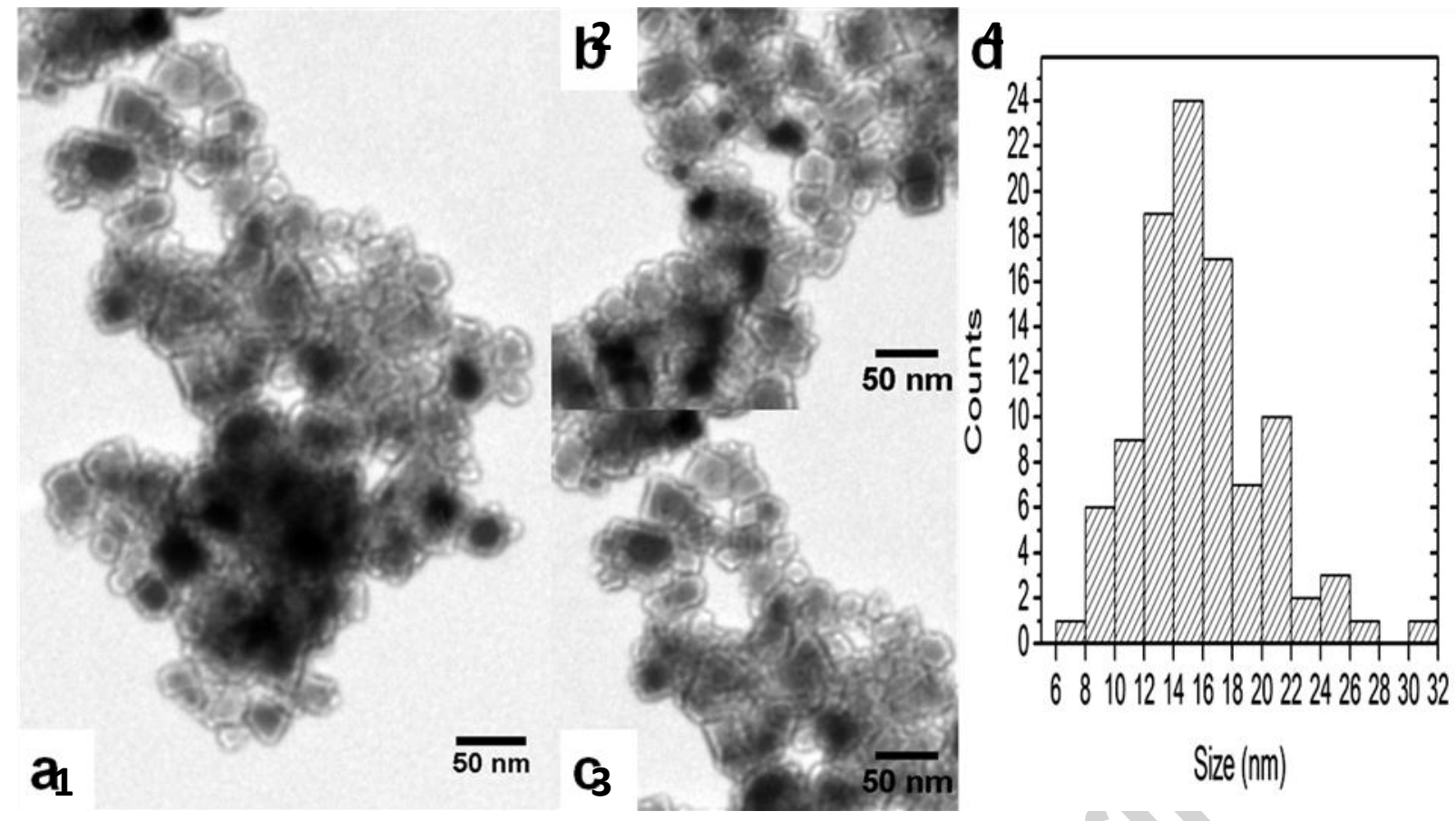

Figure 7: TEM images and size histogram of $\mathrm{Ni}_{0.4} \mathrm{Cu}_{0.2} \mathrm{Zn}_{0.4} \mathrm{Fe}_{2} \mathrm{O}_{4}$ synthesized at $\mathrm{T}=90^{\circ} \mathrm{C}, \mathrm{t}=2$ hours and for $\mathrm{P}_{\mathrm{diss}}=46.27$ Watt $(1,2$, and 3 represent different areas of the sample; 4 the size histogram). 


\section{ACCEPTED MANUSCRIPT}
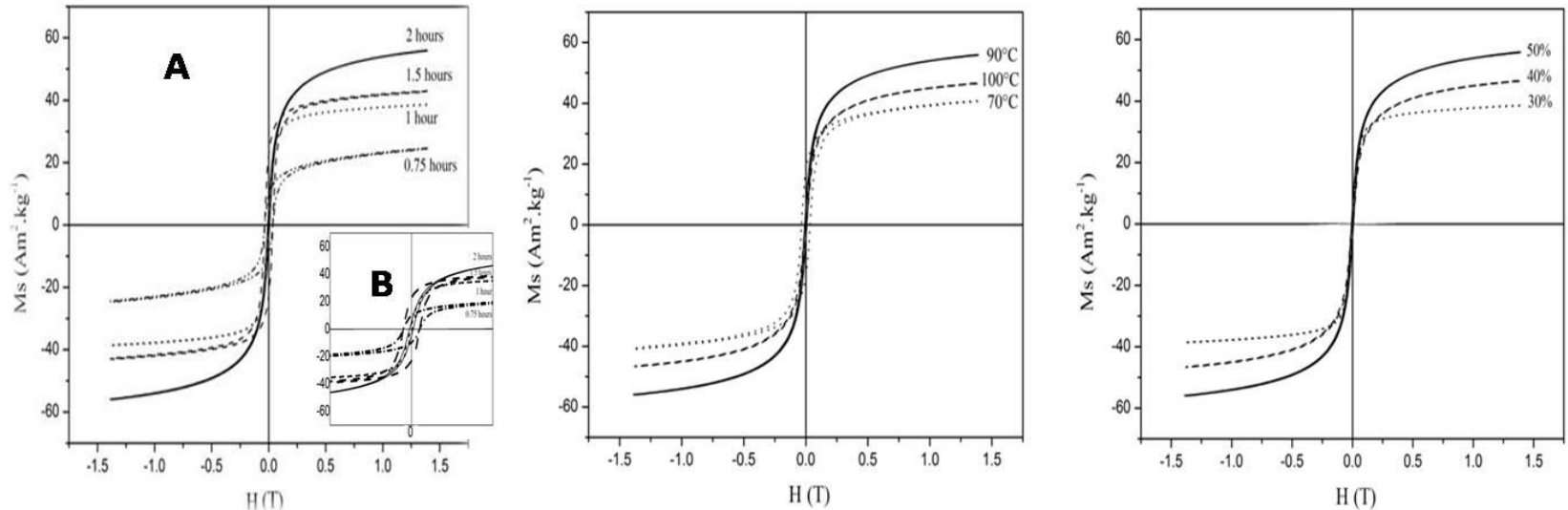

Figure 8: Hysteresis loop for the $\mathrm{Ni}_{0.4} \mathrm{Cu}_{0.2} \mathrm{Zn}_{0.4} \mathrm{Fe}_{2} \mathrm{O}_{4}$

(a)

(b)

(c)

(A) Room temperature Room temperature hysteresis Room temperature hysteresis hysteresis loop for the ferrites loop for the ferrites loop for the ferrites at at different synthesis duration synthesized at 70, 90 and different dissipated power at at $90^{\circ} \mathrm{C}$ (Dissipated power $=100^{\circ} \mathrm{C}$ for 2 hours (Dissipated $90^{\circ} \mathrm{C}$ for 2 hours.

$46.27 \quad$ Watt). $\quad(B)$ power $=46.27$ Watt $)$.

Aggrandizement

Table 1: Dissipated power results for different amplitudes.

\begin{tabular}{cc}
\hline Apmlitude $(\%)$ & Dissipated power $\left( \pm 3 \times 10^{-4}\right.$ Watt $)[21]$ \\
\hline 30 & 28.03 \\
40 & 38.23 \\
50 & 46.27 \\
\hline
\end{tabular}

Table 2: Data obtained for $\mathrm{Ni}_{0.4} \mathrm{Cu}_{0.2} \mathrm{Zn}_{0.4} \mathrm{Fe}_{2} \mathrm{O}_{4}$ ferrites nanostructures synthesized through different methods.

\begin{tabular}{|c|c|c|c|c|}
\hline Ferrite Nature & $\begin{array}{c}\text { Synthesis } \\
\text { Method }\end{array}$ & $\begin{array}{c}\text { Duration } \\
\text { (hours) }\end{array}$ & $\begin{array}{c}\text { Temperature } \\
\left({ }^{\circ} \mathrm{C}\right)\end{array}$ & Reference \\
\hline $\mathrm{Ni}_{0.4} \mathrm{Cu}_{0.2} \mathrm{Zn}_{0.4} \mathrm{Fe}_{2} \mathrm{O}_{4}$ & Sol-gel + RTA & & & [6] \\
\hline $\mathrm{Ni}_{0.4} \mathrm{Cu}_{0.2} \mathrm{Zn}_{0.4} \mathrm{Fe}_{2} \mathrm{O}_{4}$ & $\begin{array}{l}\text { reverse micelle } \\
\text { process }\end{array}$ & $>38$ & Calcination (600) & [8] \\
\hline $\mathrm{Ni}_{0.4} \mathrm{Cu}_{0.2} \mathrm{Zn}_{0.4} \mathrm{Fe}_{2} \mathrm{O}_{4}$ & Citrate precursor & 4 & $\begin{array}{c}\text { Calcination }(600 \\
1 \mathrm{~h})+ \text { Sintering } \\
(900,3 \mathrm{~h})\end{array}$ & [9] \\
\hline
\end{tabular}




\begin{tabular}{ccccc}
$\mathrm{Ni}_{0.4} \mathrm{Cu}_{0.2} \mathrm{Zn}_{0.4} \mathrm{Fe}_{2} \mathrm{O}_{4}$ & Ceramic method & 12 & Calcination (900) & {$[10]$} \\
$\mathrm{Ni}_{0.4} \mathrm{Cu}_{0.2} \mathrm{Zn}_{0.4} \mathrm{Fe}_{2} \mathrm{O}_{4}$ & $\begin{array}{c}\text { Gelatin } \\
\text { precursor } \\
\text { method }\end{array}$ & 2 & $\begin{array}{c}\text { Ignition of } \\
\text { precursor at } 550\end{array}$ & {$[11]$} \\
$\mathrm{Ni}_{0.4} \mathrm{Cu}_{0.2} \mathrm{Zn}_{0.4} \mathrm{Fe}_{2} \mathrm{O}_{4}$ & Ultrasound & 2 & $\begin{array}{c}\text { Co precipitation at } \\
90\end{array}$ & This work \\
\hline
\end{tabular}

Table 3: Crystallite size, lattice parameters (a) and cell volume (V) of $\mathrm{Ni}_{0.4} \mathrm{Cu}_{0.2} \mathrm{Zn}_{0.4} \mathrm{Fe}_{2} \mathrm{O}_{4}$ nano-crystals for two synthesis duration.

\begin{tabular}{cccc}
\hline Conditions & $\begin{array}{c}\text { Crystallite size } \\
( \pm 1 \mathrm{~nm})[24]\end{array}$ & $\mathrm{a}(\AA)$ & $\mathrm{V}\left(\AA^{3}\right)$ \\
& 12.10 & $8.411(1)$ & $595.027(3)$ \\
$\mathrm{t}=1.5$ hours; $\mathrm{T}=90^{\circ} \mathrm{C}$ & 16.12 & $8.412(1)$ & $595.273(6)$ \\
$\mathrm{t}=2$ hours; $\mathrm{T}=90^{\circ} \mathrm{C}$ & $(16-38)[11]$ & $8.37[8]$ & \\
& & & \\
\hline
\end{tabular}

Table 4: Crystallite size, lattice parameters and cell volume (V) of $\mathrm{Ni}_{0.4} \mathrm{Cu}_{0.2} \mathrm{Zn}_{0.4} \mathrm{Fe}_{2} \mathrm{O}_{4}$ nano-crystals for three synthesis temperatures for 2 hours $\left(\mathrm{P}_{\text {diss }}=46.27 \mathrm{Watt}\right)$.

\begin{tabular}{cccc}
\hline Conditions & $\begin{array}{c}\text { Crystallite size } \\
( \pm 1 \mathrm{~nm})[24]\end{array}$ & $\mathbf{a}(\AA)$ & $\mathbf{V}\left(\AA^{\mathbf{3}}\right)$ \\
& 15.90 & $8.414(4)$ & $595.757(8)$ \\
$\mathrm{T}=70^{\circ} \mathrm{C}$ & 16.12 & $8.412(1)$ & $595.273(6)$ \\
$\mathrm{T}=90^{\circ} \mathrm{C}$ & 17.87 & $8.411(4)$ & $595.111(7)$ \\
$\mathrm{T}=100^{\circ} \mathrm{C}$ & $18.7[23]$ & & \\
& & & \\
\hline
\end{tabular}


Table 5: Crystallite size, lattice parameters and cell volume of $\mathrm{Ni}_{0.4} \mathrm{Cu}_{0.2} \mathrm{Zn}_{0.4} \mathrm{Fe}_{2} \mathrm{O}_{4}$ nano-crystals at different dissipated power.

\begin{tabular}{cccc}
\hline Conditions & $\begin{array}{c}\text { Crystallite size } \\
( \pm 1 \mathrm{~nm})[24]\end{array}$ & $\mathbf{a}(\AA)$ & $\mathbf{V}\left(\AA^{3}\right)$ \\
\hline $\mathrm{P}_{\text {diss }}=28.03$ Watt & 12.82 & $8.411(1)$ & $595.056(7)$ \\
$\mathrm{P}_{\text {diss }}=38.23$ Watt & 15.01 & $8.411(2)$ & $595.077(9)$ \\
$\mathrm{P}_{\text {diss }}=46.27$ Watt & 16.12 & $8.412(1)$ & $595.273(6)$ \\
\hline
\end{tabular}

Table 6: Specific surface area and average pore size of samples obtained at different initial conditions

\begin{tabular}{ccc}
\hline Initial conditions & $\mathrm{S}_{\mathrm{BET}}\left(\mathrm{m}^{2} \cdot \mathrm{g}^{-1}\right)$ & Average pore size $(\mathrm{nm})$ \\
\hline time $=2.0 \mathrm{~h} ; \theta=90^{\circ} \mathrm{C} ; \mathrm{P}_{\text {diss }}=46.27 \mathrm{Watt}$ & 127 & 6.3 \\
time$=2.0 \mathrm{~h} ; \theta=70^{\circ} \mathrm{C} ; \mathrm{P}_{\text {diss }}=46.27 \mathrm{Watt}$ & 112 & 8.4 \\
time=2.0h; $\theta=100^{\circ} \mathrm{C} ; \mathrm{P}_{\text {diss }}=46.27 \mathrm{Watt}$ & 138 & 5.8 \\
time$=2.0 \mathrm{~h} ; \theta=90^{\circ} \mathrm{C} ; \mathrm{P}_{\text {diss }}=38.23 \mathrm{Watt}$ & 120 & 7.5 \\
time=2.0h; $\theta=90^{\circ} \mathrm{C} ; \mathrm{P}_{\text {diss }}=28.03 \mathrm{Watt}$ & 113 & 6.1 \\
\hline
\end{tabular}

Table 7: Magnetic parameters of synthesized NiCuZn ferrites.

\begin{tabular}{clcc}
\hline Ferrite Nature & Synthesis Method & $\begin{array}{c}\text { Saturation } \\
\text { magnetization Ms }\end{array}$ & Reference \\
\hline $\mathrm{Ni}_{0.4} \mathrm{Cu}_{0.2} \mathrm{Zn}_{0.4} \mathrm{Fe}_{2} \mathrm{O}_{4}$ & Sol-gel + RTA & $*$ & {$[6]$} \\
$\mathrm{Ni}_{0.4} \mathrm{Cu}_{0.2} \mathrm{Zn}_{0.4} \mathrm{Fe}_{2} \mathrm{O}_{4}$ & $\begin{array}{l}\text { reverse micelle process } \\
\text { with Calcination }\end{array}$ & $*$ & {$[8]$} \\
$\mathrm{Ni}_{0.4} \mathrm{Cu}_{0.2} \mathrm{Zn}_{0.4} \mathrm{Fe}_{2} \mathrm{O}_{4}$ & $\begin{array}{l}\text { Citrate precursor } \\
\text { with Calcination }\end{array}$ & $92 \mathrm{Am}^{2} \cdot \mathrm{kg}^{-1}$ & {$[9]$} \\
$\mathrm{Ni}_{0.4} \mathrm{Cu}_{0.2} \mathrm{Zn}_{0.4} \mathrm{Fe}_{2} \mathrm{O}_{4}$ & $\begin{array}{l}\text { Ceramic method } \\
\text { with Calcination }\end{array}$ & $72 \mathrm{Am}^{2} \cdot \mathrm{kg}^{-1}$ & \\
& & & \\
\hline
\end{tabular}




\section{ACCEPTED MANUSCRIPT}

$\mathrm{Ni}_{0.4} \mathrm{Cu}_{0.2} \mathrm{Zn}_{0.4} \mathrm{Fe}_{2} \mathrm{O}_{4} \quad$ Gelatin precursor method

- Coprecipitation experiments were carried out with ultrasound.

- $\quad$ The spinel ferrite NiCuZn was perfectly synthesized by ultrasound.

- The saturation magnetization and crystals size are found to be correlated as the dissipated power was varied. 